\title{
Immunoglobulin profiles of the chronic antibody response: discussion in relation to brucellosis infections
}

\author{
R. G. White \\ M.A., D.M., F.R.C.P., F.R.C.Path., F.R.S.E. \\ Department of Bacteriology and Immunology, University of Glasgow, \\ Western Infirmary, Glasgow
}

\begin{abstract}
Summary
The use of a sensitive and quantitative radioimmunoassay has enabled much finer dissection of the immunoglobulin-antibody profiles for an individual immune response. The kinetics of the response are considered in relation to the switch from IgM to IgG antibody production. In the domestic fowl, the kinetics of this switch varied with different antigens: whereas the response to a thymus-dependent antigen proceeded through a brief 19S response to a declining $7 \mathrm{~S}$ response, the response to a thymus-independent antigen failed to switch from 19S to $7 \mathrm{~S}$ for several weeks and consisted of repeated excursions of 19S antibodies. When injected intravenously and simultaneously, Salmonella adelaide $\mathbf{O}$ (killed) organisms (thymusindependent) and sheep red cells (thymus-dependent) interact so that the response to the latter fails to switch from 19S to $7 \mathrm{~S}$ and consists of repeated excursions of 19S antibody. The changed character of the sheep red cell response is interpreted as being due to lack of 7S antibody. Passive antibody to either sheep red cells or to $S$. adelaide produced an inhibition of the sheep red rell response so that only one excursion of 19S antibody was observed.

The use of the radio-immunoassay enables an independent measurement of all IgM, IgG and IgA antibody to the surface antigen of Brucella obortus. The test, when applied to forty-six sera from individuals with various types of brucellosis, successfully detected antibody in many instances in which conventional serological tests were negative, and such antibody (if IgM) was associated with acute or (if IgG or IgA) with chronic cases of brucellosis. The radioassay test should prove highly valuable effectively to eliminate, in individual patients, the diagnosis of brucellosis based on the inability of conventional tests to detect significant antibody levels.
\end{abstract}

IN a chronic disease like brucellosis, serology comes to occupy a dominant role in diagnosis since the bacteriologist too often fails to isolate the causal organism from blood, or from marrow obtained by sternal puncture, or from liver obtained at biopsy.
Moreover, it has been postulated (Anderson et al., 1964; Reddin et al., 1965; Coghlan and Weir, 1967) that a determination of the immunoglobulin class of Brucella antibody present in serum allows determination of the stage of the disease, whether acute, subacute or chronic. Up to the present, the estimation of antibody to B. abortus in terms of immunoglobulin class has been deduced for clinical diagnostic purposes from the results of direct and indirect agglutination tests, in presence and absence of 2-mercaptoethanol and by the complement fixation test (Kerr et al., 1966a, b; 1968). In the present approach (Parratt et al., 1977) antibody in each of the three classes IgM, IgG and IgA has been determined directly by the method of radio-immunoassay; but before the results obtained in Brucella infections in man are discussed, consideration must be given to the control processes which determine the sequential production of the different immunoglobulin classes of antibody.

The response of man to all antigenic stimuli may involve the subsequent production of antibody in any or all of the immunoglobulin forms IgM, IgG, IgA, IgD and IgE. At present it is not understood why this antibody response needs to be so complex, although it is known that all these molecular forms of antibody have different heavy chains which confer different biological activities. It seems clear that evolutionary progress among the higher vertebrates has coincided with the progressive development of more immunoglobulin classes or subclasses of antibody. The first immunoglobulin class to be made in any immune response is $\operatorname{IgM}$ and the biosynthesis of other immunoglobulins is directly dependent on this prior IgM response. The clearest evidence of this is that antibody specific for the $\mu$ chain of IgM, injected into neonatal mice (Lawton et al., 1972; Manning and Jutila, 1972a, b; Murgita, Mattioli and Tomasi, 1973), or into chick embryos in the egg (Kincade et al., 1970; Kincade and Cooper, 1971) or used in lymphoid cultures in vitro (Pierce, Solliday and Asofsky, 1972) causes suppression of subsequent IgM production and also of other 
immunoglobulins. The injection of antibody against the $\gamma$ chain of chicken $7 \mathrm{~S} \mathrm{Ig} \mathrm{(IgY} \mathrm{or} \mathrm{IgG)} \mathrm{will} \mathrm{pre-}$ vent subsequent production of IgG and IgA but allow production of IgM and the later switch from IgM to IgG occurs within the same plasma cell derivatives (plasmacytes). Although the data, from chickens, of Kincade and Cooper (1971) support the hypothesis that IgA production depends necessarily on a similar later $\mathbf{I g G} \rightarrow \operatorname{IgA}$ switch, this was not borne out by the data obtained by Martin and Leslie (1974) in chickens and by the in vitro data of Pierce et al. (1972). All of these experiments supported the possibility of a direct IgM $\rightarrow$ IgA switch. The most likely explanation for the effects of anti- $\mu$ antiserum on the immune system is a reaction with IgM receptors on the surface of virgin precursor B cells, including those which would eventually give rise to IgA and IgG producers. Consideration of the immunoglobulin composition of sera must take account of immunoglobulin turnover. In man, IgG has the longest half-life ( 23 days approximately at a normal serum level of IgG) as compared with 6 days for $\mathrm{IgA}$ and 5 days for IgM. IgG will, therefore, tend to build up and persist, relative to other immunoglobulins, in the sera from chronic infections.

What controls the switch from one immunoglobulin class to the next? In the adult antibody response it has long been established that specific antibody can interfere with the production of the same specificity of antibody (Uhr and Möller, 1968). This demonstration usually involves the injection of an antiserum (principally this is IgG antibody from an hyperimmune serum) before or at the same time as the injection of antigen. This suppresses both IgM and IgG responses, and has been shown to do this in a variety of animal species. More recently, the same suppressive action has been shown for IgA and IgE antibodies (Strannegard and Belin, 1970; Ishizaka and Okudaira, 1972).

The suggestion is that not only are the antibody responses IgM, IgG, IgA and IgE linked in succession but that negative feedback loops exist so that antibody of one class can suppress its own synthesis; the antibody of succeeding classes, expecially IgG, can exert feedback control on antibody of the previous immunoglobulin forms. Clearly there are very many possibilities, but in order to make this presentation tolerable, let us limit consideration to IgM and IgG, with lesser attention to IgA.

Many sources state that both IgM and IgG antibodies have a suppressive action. In the mouse response to sheep erythrocytes (a thymus-dependent antigen at least at low antigen dosage), purified $19 \mathrm{~S}$ antibody consistently increased the primary response. Antibody of the same specificity, which was $7 \mathrm{~S}$, consistently suppressed the response (Henry and Jerne, 1967); and these authors attributed the suppressive effects of $19 \mathrm{~S}$, described by others, as due to varying degrees of contamination of the $19 \mathrm{~S}$ preparations with 7S antibody. Others have found that while a really high dose of $19 \mathrm{~S}$ antibody is suppressive, lower doses are able to enhance the antibody response (Möller and Wigzell, 1965). The present author's own experiments in the domestic fowl, have consistently confirmed the ability of IgM antibody to produce positive rather than negative feedback. Figure 1 shows the results of increasing doses of IgM antibody given at the same time as the antigenic stimulus: all doses produced an increase in plaque numbers at 6 days of a primary response. It was also found that IgM antibody generally enhanced the response when injected over a range of different times relative to the antigen injection (Fig. 2). Contrariwise, the 7S antibody was always suppressive of the IgM plaque-response, being strongly so when given early in the response.

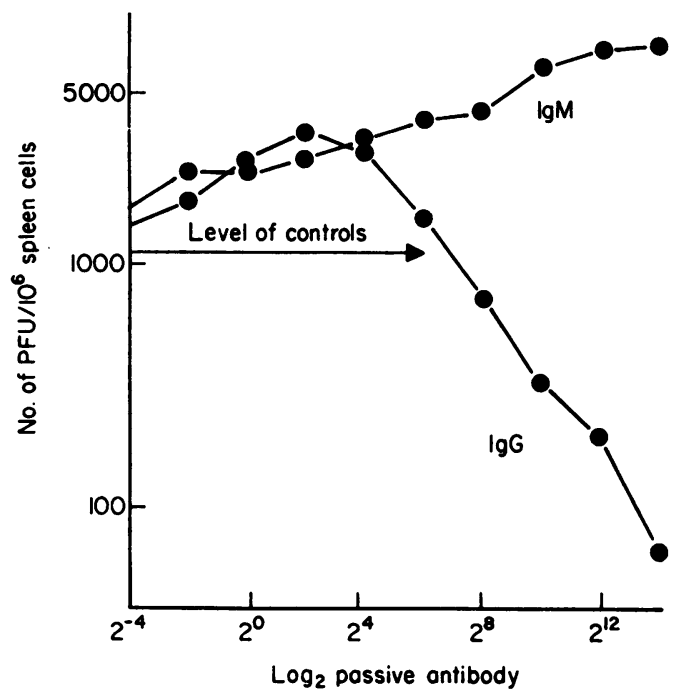

FIG. 1. Effect of increasing amounts of 7S, IgG or 19S, IgM antibody given intravenously to a young fowl on the antibody response at 6 days as judged by the counts of plaque-forming units (PF U) in $10^{6}$ spleen cells. Note that all doses of IgM antibody enhanced the response, whereas low doses of IgG antibody enhanced but higher doses produced increasing depression of the response. (Data from experiments with K. H. Nielsen.)

The ability of 7S antibody to produce negative feedback is governed by the avidity of the antibody produced. During the progress of an immunological response there is a progressive rise of antibody avidity, at least if the antigen dose is maintained low. High avidity antibodies are more competent to suppress the immunological response than low avidity antibody (Walker and Siskind, 1968). It is 


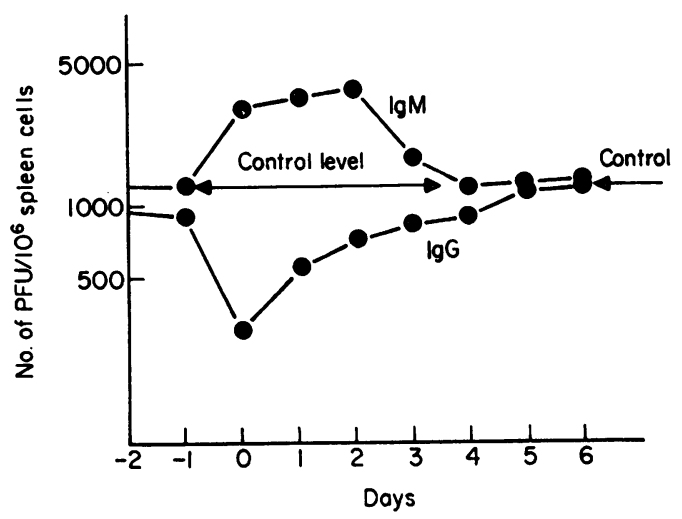

Fig. 2. Effect of a single dose of antibody (7S, IgG or $19 S$, IgM) given intravenously to a young fowl at various times from 1 day before to 6 days after an intravenous injection of $2 \mathrm{mg}$ human serum albumin (antigen). The ordinate expressed the count of plaqueforming units from $10^{6}$ spleen cells at 6 days after antigen. Note that 19S, IgM antibody always enhanced and $7 \mathrm{~S}$, IgG antibody always depressed the immune response. (Data from experiments with $K$. H. Nielsen.)

easy with 7S IgG antibody to suppress the 19S IgM primary response; relatively easy to suppress with hyperimmune serum the $7 \mathrm{~S} \mathrm{IgG} \mathrm{primary} \mathrm{response;}$ but difficult to suppress the $7 \mathrm{~S}$ IgG secondary response.

So far, the results quoted relate to thymus-dependent antigens. Thymus-independent antigens are generally regarded as stimulating B cells directly (without aid from macrophages or T-cells) and leading to responses which, at least initially, are exclusively 19S antibody. T-independent immunogens give us the opportunity to study antibody homoeostasis in the absence of $7 \mathrm{~S}$ antibody. Figure 3 shows the response of individual chickens to an injection of $10^{9}$ heat-killed Salmonella adelaide. The antibody which localizes to the surface of these bacilli (mainly anti-O) was estimated by a radioimmunoassay in which IgM or IgG antibody was measured independently of $7 \mathrm{~S}$ antibody. It can be seen that the resulting IgM response is a cyclical sequence of several peaks of decreasing magnitude. They repeat every 10 days for four cycles before they become dys-synchronous in different animals. During this period of 19S antibody peaks, 7S antibody is undetectable but increases slowly from about $\mathbf{4 0}$ days.

The explanation of this antibody profile appears to depend on the following. The antigen generates a 19S antibody response which eventually reaches sufficient concentration to exert negative feedback. However, since there is no shift to $7 \mathrm{~S}$ antibody and $19 \mathrm{~S}$ antibody has a very short duration (half-life of $18 \mathrm{hr}$ ), suppression is temporary; also, since bacterial lipopolysaccharide is persistent within the tissues, another cycle of $19 \mathrm{~S}$ antibody is irritated, and so on until $7 \mathrm{~S}$ antibody makes its appearance in sufficient amounts to secure permanent negative feedback of the response. As would be expected, the cycles of $19 \mathrm{~S}$ antibody can be brought to a

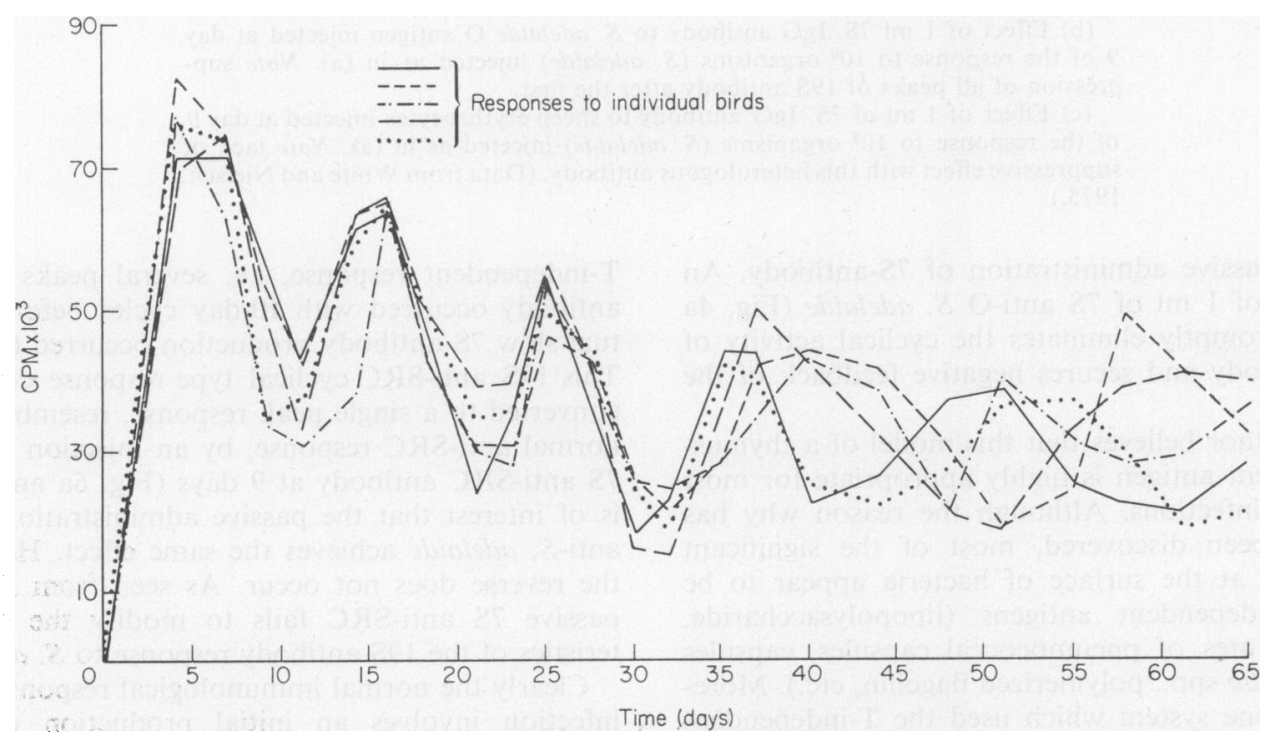

Fig. 3. Antibody responses of individual adult fowl to $10^{\circ}$ Salmonella adelaide $\mathrm{O}$ micro-organisms injected i.v. 19S antibody levels were estimated by radio-assay in the five birds at times up to 65 days. Note the cyclical response of $19 S$ antibody with peaks at days 4-7, 14-16, 25 and 35-37 days. (Data from White and Nielsen, 1975.) 


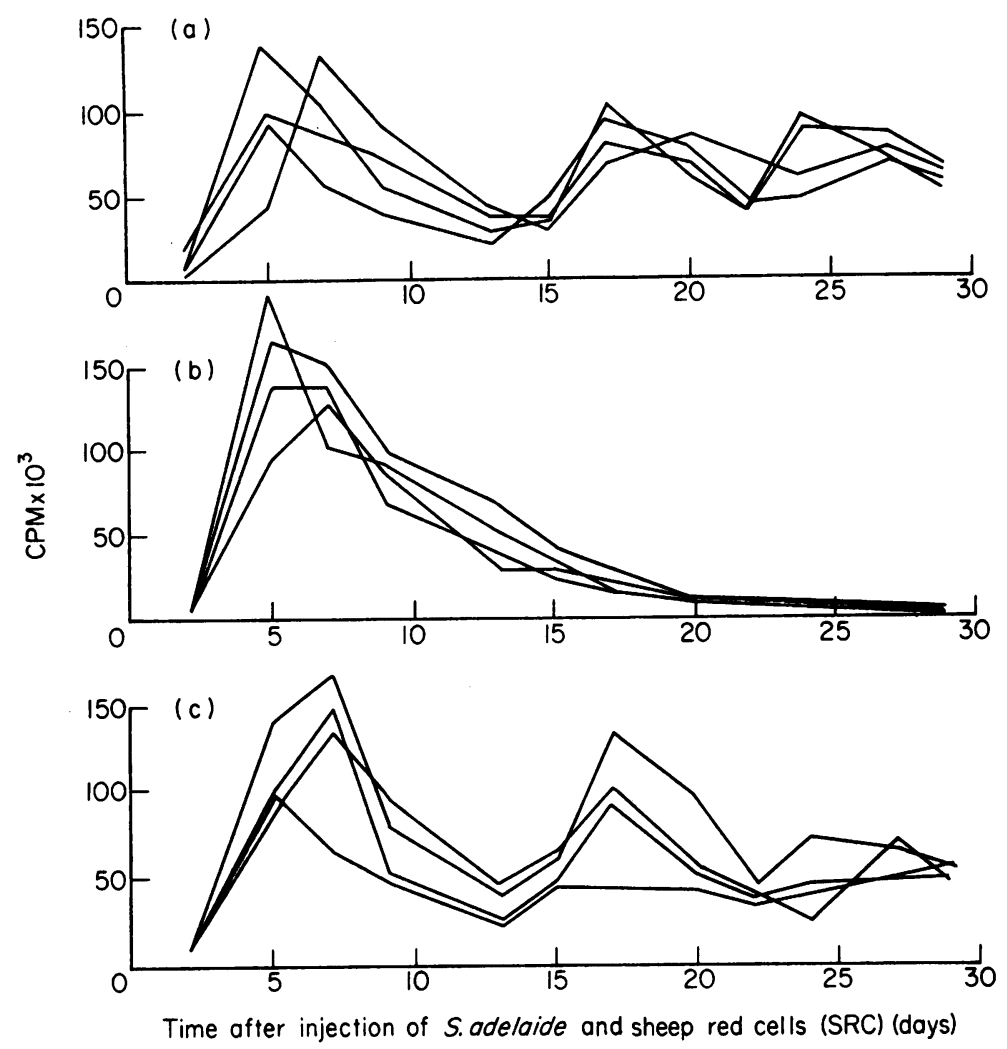

FIG. 4. (a) Antibody responses of individual adult fowl to an injection (day 0 ) of $10^{\circ}$ Salmonella adelaide $\mathrm{O}$ organisms. Note cyclical response of $19 \mathrm{~S}$ antibody, persisting up to 30 days.

(b) Effect of $1 \mathrm{ml} 7 \mathrm{~S}$, IgG antibody to $S$. adelaide $\mathrm{O}$ antigen injected at day 9 of the response to $10^{\circ}$ organisms ( $S$. adelaide) injected as in (a). Note suppression of all peaks of $19 S$ antibody after the first.

(c) Effect of $1 \mathrm{ml}$ of $7 \mathrm{~S}$, IgG antibody to sheep erythrocytes injected at day 9 of the response to $10^{9}$ organisms ( $S$. adelaide) injected as in (a). Note lack of suppressive effect with this heterologous antibody. (Data from White and Nielsen, 1975.)

halt by passive administration of 7S-antibody. An injection of $1 \mathrm{ml}$ of $7 \mathrm{~S}$ anti-O $S$. adelaide (Fig. $4 \mathrm{a}$ and b) promptly eliminates the cyclical activity of $19 S$ antibody and secures negative feedback of the response.

The author believes that this model of a thymusindependent antigen is highly appropriate for most bacterial infections. Although the reason why has not yet been discovered, most of the significant molecules at the surface of bacteria appear to be thymus-independent antigens (lipopolysaccharide, carbohydrates of pneumococcal capsules, capsules of Klebsiella spp., polymerized flagellin, etc.). Moreover, in one system which used the T-independent $S$. adelaide together with T-dependent sheep erythrocytes (SRC), the agglutinin response to the latter eventually assumed all the characteristics of a
T-independent response, i.e. several peaks of $19 \mathrm{~S}$ antibody occurred with 10-day cycles before eventual slow 7S antibody production occurred (Fig. 5). This 19S anti-SRC cyclical type response could be converted to a single peak response, resembling the normal anti-SRC response, by an injection of $1 \mathrm{ml}$ $7 \mathrm{~S}$ anti-SRC antibody at 9 days (Fig. 6a and b). It is of interest that the passive administration of $7 \mathrm{~S}$ anti-S. adelaide achieves the same effect. However, the reverse does not occur. As seen from Fig. 4c, passive 7S anti-SRC fails to modify the characteristics of the 19S antibady response to $S$. adelaide.

Clearly the normal immunological response to an infection involves an initial production of $\operatorname{IgM}$ antibody followed by IgG antibody, and on the basis of the foregoing arguments the appearance of the latter determines the decline of IgM antibody 


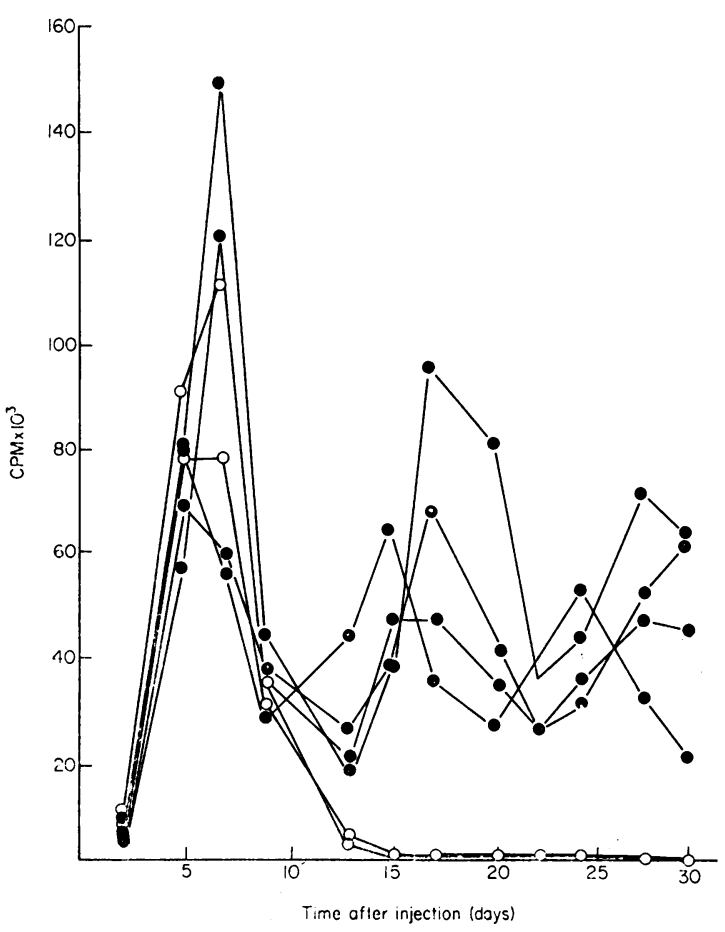

FIG. 5. Effect of an injection of $10^{9}$ Salmonella adelaide on the serum antibody response, as detected by radioassay of 19S antibody, to the simultaneous injection of $10^{10}$ sheep red cells. Adult fowl were injected at day 0 and serum antibody levels followed for 30 days. Note that the simultaneous injection of the bacillary antigen has modified the response to sheep red cells so that it fails to terminate at 15 days and goes through further cycles of $19 \mathrm{~S}$ antibody production. $\mathrm{O}-\mathrm{O}$ 19S antibody to SRC in chicken injected with SRC. 19S antibody to SRC in chickens injected with SRC+S. adelaide. (Data from White and Nielsen, 1975.)

levels. But this IgM $\rightarrow$ IgG antibody switch can be delayed, e.g. by $\mathrm{T}$-independent antigens and by an effect of T-independent antigens on the immune mechanism of T-dependent antigens. Decomplementation of the bird by treatment with cobra venom also delays the switch of IgM to IgG for the T-dependent SRBC (Nielsen and White, 1974; White and Nielsen, 1975).

The same type of radio-assay has been applied (Nielsen, Parratt and White, 1973) to the determination of the IgM, IgG and IgA types of antibody in human brucellosis. The assay has the great advantage over other methods of being a primary assay, i.e. it detects any antibody with the ability to combine with the surface antigens of Brucella organisms. It thus avoids all the distractions and complications of incomplete or blocking antibody, a notorious component of Brucella antisera.
The past decade has witnessed the gradual buildup of an increasingly complicated battery of tests for Brucella antibody; direct agglutination, agglutination after addition of anti-human globulin, agglutination after 2-mercaptoethanol, and the complement fixation test. The results of all these have been used to deduce the presence of antibody which is $\mathrm{IgM}, \mathrm{IgG}$ or IgA. This is only possible in certain instances since IgM, IgA and IgG all give rise to direct agglutination (Wilkinson, 1966), both IgM and IgG can achieve complement fixation, and the relative proportion of individualimmunoglobulins which contribute to a titre may be obscure.

The basis of the radio-immunoassay (Nielsen, et al., 1973; Parratt et al., 1977) depends upon the use of a heavy suspension of Brucella organisms, which represents an excess of antigen which can absorb all of the specific Brucella antibody in $50 \mu l$ of serum. After adequate washing, an excess of ${ }^{125 I-l a b e l l e d ~ s h e e p ~ a n t i-h u m a n ~ I g G ~(o r ~ I g M ~ o r ~}$ IgA) is added. The amount of uptake of the latter, after washing, measures the antigen-combining power of the serum. Each anti-human Ig must be specific for one of the heavy chains of IgM, IgG or IgA. Also each serum must be tested for rheumatoid factor (RF) since if this is present it will elevate falsely the recorded IgM antibody. In the case of sera with positive RF, these can be absorbed before assay with aggregated human IgG.

In acute cases of brucellosis IgM antibody would be expected in the serum without much IgG or IgA antibody. If IgG has appeared in substantial amounts and produced negative feedback of the immunological response, the IgM antibody would be expected to fall to a low level, and it can be assumed that the chronic stage of a normally evolving immunological response has been reached. In Table 1 , cases 1,2 and 3 fit with the foregoing concept of acute brucellosis. Radioactivity counts above $40 \times 10^{3}$ are regarded as significant for the presence of antibody. Thus, case 2 with 3 weeks pyrexia has high IgM antibody with low IgG antibody. Presumably cases 1 and 3 are approaching the subacute phase of disease since they already have substantial levels of IgG antibody. Case 4 is clearly a chronic case with high IgG in the absence of IgM antibody. Similarly cases 5 and 6 clearly conform with a diagnosis of acute brucellosis and cases 7 and 8 with chronic brucellosis.

It should be noted that all the first 8 cases have some positive serological finding using conventional tests. How do the latter correlate with the results of the radio-assay? Firstly, how does radio-assay of IgM antibody correlate with direct agglutination titres? Of the forty-six sera examined only nineteen showed significant titres (1:80 or above) in the direct agglutination test. Only one serum showed a 


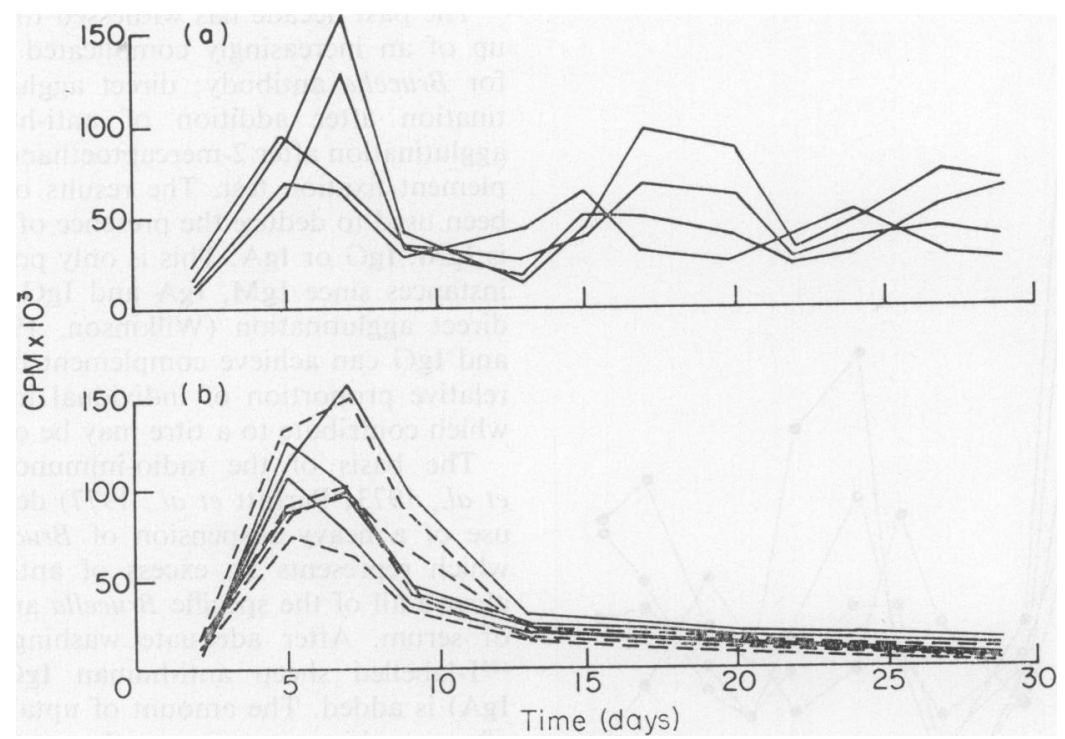

Fig. 6. (a) Antibody response to sheep red cells in individual fowls injected simultaneously with the two antigens $10^{10}$ sheep red cells and $10^{\circ}$ Salmonella adclaide. Response measured as 19S, IgM antibody by radioassay.

(b) Effect of an injection of $1 \mathrm{ml}$ of a $7 \mathrm{~S}$ antiserum at 9 days on the response to sheep red cells elicited as above. Note that passive $7 \mathrm{~S}$, IgG antibody to sheep red cells (dotted line) and passive 7S, IgG antibody to $S$. adelaide both secure feedback of the antibody response to sheep cells which is limited to a single peak. The repeated cycles of $19 \mathrm{~S}$ antibody in the control birds (a) have been eliminated by passive treatment with 7S, IgG antibody of both specificities. - - - Effect of passive 7S-anti-sheep red cells. — Effect of passive 7S-anti-S. adelaide. (Data from White and Nielsen, 1975.)

negative radio-assay and a direct agglutination titre of $1: 80$. In general, there was a very poor correlation between the radio-assay for IgM antibody and the direct agglutination. Seventeen sera with direct agglutination titres $<1: 80$ had raised concentrations of IgM antibody by radio-assay. Secondly, the indirect agglutination results correlated moderately well with IgG antibody concentrations determined by radio-assay. Similarly, radio-assay levels for IgG antibody correlated well with the titres obtained by complement fixation.

In Table 1, numbers 8-22 represent cases in which all conventional serological tests were negative. With cases $9,12,13,16$ and 20 , the radio-assay results agree with conventional tests and a diagnosis of brucellosis can be excluded. In case 10 , the radioassay results indicate acute brucellosis as suggested by the increased IgM antibody level. The findings of case 14 indicate chronic brucellosis and those of case 15 indicate a low level of residual antibody, although it is atypical to find that this is IgM antibody. In cases 17, 18 and 19 the diagnosis of brucellosis is supported, and radio-assay reveals antibody undetected by the conventional tests. Case 21
(Payne, 1974) is very interesting in that repeated conventional tests in several different laboratories proved negative in spite of the isolation of $B$. abortus from the blood. The serum radio-assay indicated high concentrations of IgM and IgG antibody which confirm the relapse of a chronic brucellosis infection. Case 22 yielded radio-assay results (high IgA antibody) which were compatible with a diagnosis of chronic brucellosis.

It remains to be determined whether this quantitative and sensitive primary assay for Brucella antibody will prove useful for the diagnosis of a relapse during the course of chronic brucellosis. This could be signalled by a change from a low IgG antibody level to a rising peak of IgM with later IgG rise. The significance of the results might be greatly increased by the contemporaneous testing of sequential serum samples.

With conventional tests the diagnosis of brucellosis could never be excluded, even if the agglutination test, the mercaptoethanol test, the complement fixation test and the anti-human globulin findings were all negative (Payne, 1974). The use of a sensitive radio-assay which covers the primary reactivity of Brucella antibody of IgM, IgG and IgA classes 
TABLE 1. The results obtained with this type of radio-immunoassay (RIA) in twenty-two patients suspected of brucellosis. The first eight cases have positive conventional tests indicating Brucella infection. Cases 9-22 have negative conventional tests for Brucella antibody

\begin{tabular}{|c|c|c|c|c|c|c|c|}
\hline \multirow{2}{*}{$\begin{array}{l}\text { Case } \\
\text { no. }\end{array}$} & \multirow[b]{2}{*}{ Clinical data } & \multicolumn{3}{|c|}{ RIA ct $/ \mathrm{min} \times 10^{3}$} & \multirow{2}{*}{$\begin{array}{l}\text { Direct } \\
\text { agg. titre }\end{array}$} & \multirow{2}{*}{$\begin{array}{l}\text { Indirect } \\
\text { agg. titre }\end{array}$} & \multirow[b]{2}{*}{ CFT titre } \\
\hline & & IgM & IgG & IgA & & & \\
\hline 1 & Positive blood-culture of $B$. abortus & & & & & & \\
\hline & 2 months previously & 103 & 109 & 30 & 640 & 5120 & 256 \\
\hline 2 & Pyrexia 3 weeks & 68 & 34 & 6 & 160 & 640 & 256 \\
\hline 3 & Vet pricked by inoculation needle & 71 & 65 & 8 & $<20$ & 2560 & 256 \\
\hline & pyrexia. Son with brucellosis & 4 & 140 & 10 & 5120 & 5120 & 256 \\
\hline 5 & Pyrexia with no obvious cause, of & & & & & & \\
\hline 6 & $\begin{array}{l}2 \text { weeks' duration } \\
\text { Dairy farmhand: pyrexia } 2 \text { weeks. }\end{array}$ & 200 & 138 & 47 & 1280 & 1280 & 64 \\
\hline & Rash and joint pains & 164 & 0 & 0 & 80 & 20 & $<4$ \\
\hline 7 & $\begin{array}{l}\text { Slaughterman with backache and } \\
\text { febrile episodes }\end{array}$ & 26 & 63 & 0 & 160 & 320 & 16 \\
\hline 8 & $\begin{array}{l}\text { Malaise, giddiness, nausea, head- } \\
\text { ache, and depression }\end{array}$ & 27 & 63 & 0 & 1280 & 2560 & 256 \\
\hline 9 & Farmer: chronic ill health & 4 & 13 & 0 & $<20$ & $<20$ & $<4$ \\
\hline 10 & $\begin{array}{l}\text { Farm dweller: intake of raw milk; } \\
\text { painful hip }\end{array}$ & 82 & 0 & 0 & $<20$ & $<20$ & $<4$ \\
\hline 11 & Farmer's wife: pyrexia of uncertain & & & & & & \\
\hline & cause: rigors and backache & 53 & 0 & 14 & $<20$ & $<20$ & $<4$ \\
\hline 12 & Veterinary staff: routine check & 0 & 7 & 0 & $<20$ & 40 & 4 \\
\hline 13 & Veterinary staff: routine check & 0 & 29 & 0 & 20 & 40 & 8 \\
\hline 14 & Farmer with recurrent fever & 24 & 15 & 58 & $<20$ & 20 & $<4$ \\
\hline 15 & Recovered from brucellosis & 55 & 0 & 0 & 40 & 20 & $<4$ \\
\hline 16 & Farmer: history of aches and pains & 0 & 0 & 0 & $<20$ & $<20$ & $<4$ \\
\hline 17 & Cowman: history of multiple & & & & & & \\
\hline & complaints & 25 & 75 & 27 & $<20$ & $<20$ & 4 \\
\hline 18 & Recurrent pyrexia & 65 & 33 & 0 & $<20$ & $<20$ & $<4$ \\
\hline 19 & Chronic brucellosis & 113 & 28 & 0 & 80 & 40 & $<4$ \\
\hline 20 & Farmer with 3rd episode of pyrexia & & & & & & \\
\hline 21 & $\begin{array}{l}\text { of unknown origin } \\
\text { Brucella sp. isolated from blood }\end{array}$ & 0 & 0 & 63 & $<20$ & $<20$ & $<4$ \\
\hline & $\begin{array}{l}\text { 1966. Negative serology. Several } \\
\text { relapses. Possibly new relapse }\end{array}$ & 84 & 70 & $\mathbf{0}$ & $<20$ & $<20$ & $<4$ \\
\hline 22 & Herd manageress: recurrent fever & 3 & 42 & 89 & $<20$ & 40 & 8 \\
\hline
\end{tabular}

should go a long way towards allowing the exclusion of a brucellosis diagnosis - always provided that the patient is not incapacitated by a severe immunological deficiency.

\section{References}

Anderson, R.K., Jenness, R., Brumfield, H.P. \& Gouch, P. (1964) Brucella-agglutinating antibodies: relation of mercaptoethanol stability to complement fixation. Science. New York, etc., 143, 1334.

Coghlan, J.D. \& WeIR, D.M. (1967) Antibodies in human brucellosis. British Medical Journal, 2, 269.

HENRY, C. \& JERNE, N.K. (1967) The depressive effect of 7S antibody and the enhancing effect of 19S antibody in the regulation of the primary immune response. In: Nobel Symposium No. 3: Gamma Globulins (Ed. Killander, J.) p. 421. Almqvist \& Wiksell, Stockholm.

IsHIzAKA, K. \& OKUDAIRA, H. (1972) Reaginic antibody formation in the mouse. I. Antibody-mediated suppression of reaginic antibody formation. Journal of Immunology, $109,84$.

Kerr, W.R., Coghlan, J.D., Payne, D.J.H. \& Robertson, L. (1966a) Chronic brucellosis in the practising veterinary surgeon. Veterinary Record, 79, 602.
Kerr, W.R., Coghlan, J.D., Payne, D.J.H. \& Robertson, L. (1966b) The laboratory diagnosis of chronic brucellosis. Lancet, ii, 1181.

Kerr, W.R., McCaughey, W.J., Coghlan, J.D., Payne, D.J.H., QuAIFe, R.A., Robertson, L. \& FARRELl, I.D. (1968) Techniques and interpretations in the serological diagnosis of brucellosis in man. Journal of Medical Microbiology, 1, 181.

KinCADE, P.W., \& CoOPER, M.D. (1971) Development and distribution of immunoglobulin-containing cells in the chicken. Journal of Immunology, 106, 371.

Kincade, P.W., Lawton, A.R., Bockman, D.E. \& Cooper, M.D. (1970) Suppression of immunoglobulin $G$ synthesis as the result of antibody-mediated suppression of immunoglobulin $\mathbf{M}$ synthesis in chickens. Proceedings of the National Academy of Sciences of the United States of America, 67, 1918.

Lawton, A.R., Asofsky, R., Hylton, M.B. \& Cooper, M.D. (1972) Suppression of immunoglobulin class synthesis in mice. I. Effects of treatment with antibody to $\mu$-chain. Journal of Experimental Medicine, 135, 277.

MANNING, D.D. \& JutILA, J.W. (1972a) Immunosuppression in mice injected with heterologous anti-immunoglobulin antisera. Journal of Immunology, 108, 282. 
MANNING, D.D. \& JuTILA, J.W. (1972b) Immunosuppression of mice injected with heterologous anti-immunoglobulin heavy chain antisera. Journal of Experimental Medicine, $135,1316$.

Martin, L.N. \& Leslie, G.A. (1974) IgM-forming cells as the immediate precursor of IgA-producing cells during ontogeny of the immunoglobulin-produsing system of the chicken. Journal of Immunology, 113, 120.

Möller, G. \& Wigzell, H. (1965) Antibody synthesis at the cellular level. Antibody-induced suppression of $19 \mathrm{~S}$ and $7 \mathrm{~S}$ antibody response. Journal of Experimental Medicine, $121,969$.

Murgita, R.A., Mattioli, C.A. \& Tomasi, T.B. (1973) Production of a runting syndrome and selective $\gamma \mathrm{A}$ deficiency in mice by the administration of anti-heavychain antisera. Jo:ırnal of Experimental Medicine, 138, 209.

Nielsen, K.H., Parratt, D. \& White, R.G. (1973) Quantitation of antibody to particulate antigens using a radiolabelled anti-immunoglobulin reagent: application to estimation of antibody in farmer's lung syndrome. Journal of Immunological Methods, 3, 301.

Nielsen, K.H. \& White, R.G. (1974) Effect of host decomplementation on homeostasis of antibody production in fowl. Nature. London, 250, 234.

Parratt, D., Nielsen, K.H., White, R.G. \& Payne, D.J.H. (1977) Radio-immunoassay of IgM, IgG and IgA Brucella antibodies. Lancet, i, 1075.
PAYNe, D.J.H. (1974) Chronic brucellosis. British Medical Journal, 2, 221.

Pierce, C.W., Solliday, S.M. \& Asofsky, R. (1972) Immune response in vitro. IV. Suppression of primary $\gamma \mathrm{M}, \gamma \mathrm{G}$ and $\gamma \mathrm{A}$ plaque-forming cell responses in mouse spleen cell cultures by class-specific antibody to mouse immunoglobulins. Journal of Experimental Medicine, 135, 675.

Reddin, J.L., Anderson, R.K., Jenness, R. \& SpInK, W.W. (1965) The significance of $7 \mathrm{~S}$ and macroglobulin Brucella agglutinins in human brucellosis. New England Journal of Medicine, 272, 1263.

Strannegard, O. \& Berlin, L. (1970) Suppression of reagin synthesis in rabbits by passively administered antibody. Immunology, 18, 773.

Uhr, J.W. \& Möller, G. (1968) Regulatory effect of antibody on the immune response. Advances in Immunology, $8,81$.

WALKER, J.G. \& Siskind, G.W. (1968) Effect of antibody affinity upon its ability to suppress antibody formation. Immunology, 14, 21.

White, R.G. \& NiELSEN, K.H. (1975) Interactions between the immunological responses of a thymus-independent antigen (Salmonella adelaide $\mathrm{O}$ antigen) with a thymusdependent antigen (sheep erythrocytes) in the adult bird. Immunology, 28, 959.

Wilkinson, P.C. (1966) Immunoglobulin patterns of antibodies against Brucella in man and animals. Journal of Immunology, 96, 457. 